\title{
A CRITICAL DISCOURSE ANALYSIS OF GENDER SUBJECTIVITY IN HENRY JAMES' THE PORTRAIT OF A LADY
}

\author{
Shah Mir ${ }^{1 i}$, \\ Saima Jahangir ${ }^{2}$ \\ ${ }^{1} \mathrm{PhD}$ Scholar, \\ Graduate School of Social Sciences, \\ Atilim University, \\ Ankara, Turkey \\ ${ }^{2}$ Lecturer in English, \\ LUAWMS, Wadh Campus, \\ Balochistan, Pakistan
}

\begin{abstract}
:
Reassessment and interpretation of gender dynamics in the current social order has been prevalent theme within gender discourses. The yoke of subordination borne by women as readers, writers or fictional characters in the patriarchal pyramid occupies a central space across the whole spectrum of debates. This study utilizes a qualitative mode of inquiry which is centered on textual analysis. The present study evaluates the instances of gender subjectivity and patterns of subjugation within the textual arena invested with hegemonic ideologies as depicted in the novel The Portrait of a Lady by Henry James. The paper employs feminist critical discourse analysis as a tool to analyze The Portrait of a Lady by Henry James in order to dissect the underlying ideologies present in the Victorian time period and investigates discourses of subjectivity. The findings of the study demonstrate that notwithstanding temporal advancements, gender power structures remain intact, and women continue to suffer under patriarchal power structures.
\end{abstract}

Keywords: gender subjectivity; feminine discourse, Victorian fiction, critical discourse

\section{Translator's Behavior and the "Truth-seeking-Utility-attaining" Continuum Mode of Evaluation}

From a political perspective, feminist critical discourse analysis, assesses the interrelationship of ideology, gender and power in discourse (Lazar, 2005). Fairclough (2003) believes that discourse is deeply rooted in social action because it involves both speaking and writing which is a part and parcel of society. Feminist critical discourse analysis helps in bringing out and showing the ill-presented perpetuating ideologies about women which maintains that women are

i Correspondence: email shah mir@hotmail.com 
subordinate, secondary and not equal to men. According to Lazar, FCDA (Feminist Critical Discourse Analysis) is emancipatory in nature and helps in unchaining the women in general (2005).

The Portrait of a Lady is a novel written by Henry James in 1881, and its protagonist, Isabel Archer, is introduced as a young woman with moderate means who later inherits a fortune from her uncle Mr. Touchett in England. It recounts the story of Isabel's loss of innocence and her sudden encounter with maturity and apparently willful submission to authority after her marriage to Gilbert Osmond. She chooses to go back to a failed relationship despite her vows to the contrary in the beginning. The novel has many female characters who are one way or other bound to certain ideologies which the present study is going to probe through. Lazar (2005) demonstrates that the ideologies about women are men-made and mostly hegemonic and are indoctrinated in way that are hard to perceive at first. The present research incorporates a Feminist Critical Discourse Analysis (FCDA) mode of inquiry in order to understand those underlying hegemonic ideologies held towards women in the novel The Portrait of a Lady and how they are cornered and relegated to certain roles that they reluctantly perform.

The current study explores the novel in the light of feminist critical discourse analysis in order to bring on surface the deep-seated ideologies about females, that how despite having the means to travel, despite being intelligent, they are a prey to scheming men and are assumed to be incomplete without the companionship of a man and every man thinks that they are indispensable to women and must possess them. It analyses Isabel's acceptance of her wretched lot within the dominant patriarchal narratives. The purpose of the present research is examining means for the transformation and emancipation of women, a critique of the indefensible discourses that reinforce an unjustifiable station of women within the wider social order.

\section{Methodology}

The present work attempts to account for skewed gender dynamics and investigates the construction of sexist ideologies and how these ideological frameworks sustain gender subjectivity and subordination within the landscape of The Portrait of a Lady by Henry James. The study incorporates Lazar's theory of Feminist Critical Discourse Analysis and centers itself on a qualitative mode of enquiry with regards to discursive analysis of the text. Qualitative mode of research aids in the explication of subtle meanings, definitions, concepts, metaphors, characteristics, symbols and descriptions (Berg, 2007). Utilizing a qualitative method, content analysis is afforded primacy and through content analysis, the research is narrowed down to textual analysis. Textual analysis closely analyzes the unit of analysis and is used in order to better examine the ideologies and concepts submerged in dialogues and discussions between different characters, so that accurate results would be attained. The study takes purposive sampling technique where only the female characters are focused. 


\section{Critical Discourse Analysis as the Theoretical Framework}

Critical discourse analysis as a critical approach seeks to uncover systematic powers structures that seek to dominate, govern and perpetuate socio-economic inequality, gender subjectivity and manipulation of discourse hierarchies. Taking into cognizance the general structure of Critical Discourse Analysis, Michelle M. Lazar devised a Feminist critical discourse analysis designed towards the addressing the inherent bias within language and depicts practices and assumptions associated in sustaining patriarchal ideologies. Feminist critical discourse analysis collects varied insights from feminist studies and CDA to investigate the intricate mechanism of ideology and power and see their discursive impact in preserving disparity in genders. FCDA tries to interrogate the subtle, complex and often clear ways through which hegemonic power relations, gendered assumptions are discursively sustained, negotiated, produced and challenged in various communities and contexts (Lazar, 2007). Given that it is aimed at social transformation and justice, Feminist critical discourse analysis targets to challenge discourses which establish structures and practices that implicate to encroach on certain potentials of women as human beings. The injustice that women have faced through ages, from effective gender subjectivity to closing the socio-economic workspace for better employability at par with their gender peers. This situation calls a more intensive and introspective studies carried out through the prism of feminist critical discourse analysis to address these perennial gender disempowerments. The term 'critical' from critical discourse analysis, seeks to depict certain connection which are normally hidden, such as the connection between ideology, power and language and in feminist critical discourse analysis the digging up of power relations is known as demystification or denaturalization, claiming that it demystifies common-sensical or taken for granted assumptions about gender, ascertaining that beliefs are only ideological and most of the time dims the power inequality and differential (Lazar, 2005).

Critical discourse analysis analyzes language and language use within a social context by employing a multidisciplinary approach. The social and linguistic analysis by Van Dijk (1993) proposes to have a discourse analysis with a critical approach. Van Dijk (1993) ascertains that critical discourse analysis focuses on issues such as inequality, dominance, and power relations and demonstrate how social power abuse is reproduced, resisted and enacted by text and talk in political and social context. Power and ideologies are excavated by critical discourse analysis through an organized and systematic breakdown of language, be the language spoken or written in order to analyze connections between constructions of discourse and constructions of ideologies (Van Dijk, 1993).

According to Van Dijk, the very concept of ideology is shown to emerge from sociology, discourse analysis and cognitive and social psychology (2005). Basically, ideology is a set of beliefs comprising of anticipations, goals and values. Further he adds that ideology is a cognitive process which influences the dimensions of discourse by showing the impact ideologies have on text and talk (Van Dijk, 2005).

Feminist critical discourse analysis, on the other hand, is a recent expansion of CDA. According to Jorgenson and Philips (2004), FCDA aims to investigate the connections between 
social practice and language use. Lazar (2005) states that feminist critical discourse analysis has its roots into post-structuralist and third wave feminist theories. Gender is taken to be a flexible variable that is built on a range of feminine and masculine identities across and within persons of similar biological sex and are accordingly shaped by discourse (Sunderland and Litosseliti, 2002). Taking gender as a constructed discourse, feminist critical discourse analysis makes use of Butler's (1990) concept of performativity by locating and finding everything in discourse and overlooking material and experiential aspects of power relations and identity, depicting to be interested only in providing a theory about gender, in empirical studies, and the why gender is created so in situations and authentic texts. Nartey (2020) says that gender is most of the time taken as a tool to create warped and erroneous images of women based on patriarchal gender prejudices, and these warped images of women then account for the emergence of gender ideologies that give rise to women subordination, suppression, repression, marginalization and to and regard them as the peripheral or the other.

Nartey (2020) used FCDA as a framework to unearth the strategies used in resisting inequality, discrimination and oppression of the Ghanaian or African women. In order to tackle the problem, some strategies of resistance were used, which are appreciating and calling out to sexism, rewriting narratives which demean gender, resistance to the stereotypes of gender, gender oppression, gender norms and evaluating patriarchy. Shapiro (2017) on the other hand makes use of FCDA to explore the depiction of women protagonists in movies, who are portrayed by women screenplay writers. The research shows that the women screenwriters enjoy a degree of independence and are not subject to the constraints through the portrayal of women characters by empowering them and making them independent. Khan (2019) investigates the novel The Holy Woman using FCDA and subalternity in order to deconstruct the discourses which lead to women's objectification and their constrained identity. It shows that patriarchy of South Asian society quite legitimizes the concept of othering of women as is shown by Spivak. Mendrofa (2020) researched how companies persuade women to purchase their products by controlling them hegemonically, she uses FCDA to analyze famous brands which claim to change women's appearances, especially their skin color. Ohito and Nyachae (2018) analyze the entanglements of identities, language, power and ideologies and depict the ordeal Black female writers face, by taking the help of feminist critical discourse analysis. Dalton (2015) examines sexual harassment in Japanese media and political worlds in the context of MeToo movement and she uses feminist critical approach to bring on surface the ideologies carried about these women, showing that one's experience as an individual is never given importance, but it creates movements.

\section{Analysis and Discussion}

Sohier (2015) analyses The Portrait of a Lady in order to appropriate the concept of ladyhood as originally put forth by the writer, the researcher concludes that according to Henry James ladyhood is achieved by passing ordeals and facing many torments, stating that these trials are hard to overcome, but if overcame ladyhood is attained. Neculeac (2020) utilizes Derridean 
deconstruction to lay bare certain signifiers whether ambiguous or negative. It claims Isabel Archer's portrayal is far from being discursively innocent. It bears all the hallmarks of gender construction and how a woman must function in order to subscribe to patriarchal presets of righteousness. Isabel's depiction as an experienced hardened wife who willingly goes back to her tormenter brooks a disingenuous male fantasy propagated by the author. Ms. Archer is nothing more than a product of Victorian ideologies. Furthermore, Brown (1996) describes modes of women's adherence and social existence in The Portrait of a Lady, and the modes include women as mere parasites, culturally banished, social pariahs, and the cycle of sacrifice and sale of mothers, sisters, wives and daughters, all conforming to the machination of power structures that seek to rationalize gender subjectivity.

According to Shapiro (2017), the female character portrayal is largely dependent and equally blurred by the concept of gender inequality, and that is because of the presence of gender hierarchies that feed discourses of disparity and construct means to sustain those ideologies that subtle power mechanism in the society. Lazar (2005), on the hand, describes the same process as an ideological construction that separates men and women into two classes, that of subordination and dominance in order to preserve hierarchal power relations. That in turn ensures that gender dynamics are tilted in favor of the existing power relations where women are often portrayed in a distorted and biased light, whether the distorted image is carried by the women themselves subconsciously under the influences of gender discourses or whether they are spokespersons to larger discourses. The instilled ideologies thus become too pervasive to evade or ignore. As in the novel The Portrait of a Lady, the female status is articulated according to the standards of Victorian time period and its discourse mechanisms limiting women to certain boundaries cliched classifications. The palpable voice if the narrators at pains to announce the different domains for women and men where the former must stay in the inner sphere of social order where they have to adhere to domestic chores, bringing children and taking care of the husband and the overall family and be simply an angel in the house. The novel under analysis The Portrait of a Lady has many female characters and almost all of them echo the same ideas of restricted individuality under the vice gendered subjectivity.

In order to find out the slanted ideologies about females, all the major female characters and their latent aspirations are taken into account. The female characters are Isabel Archer, Pansy Osmond, Madam Merle, Mrs. Touchett and Amy Gemini. Isabel Archer is the supposed lady of the title of the novel. She is an American parentless young woman of twenty-one and Mrs. Touchett has brought to England, who is Isabel's aunt. She is the central concern of the novel and has an amiable personality with the capacity of growth. She is innocent as well as intelligent and has a curious nature and wants to explore the world. Due to her affable and attractive qualities, many divergent characters are charmed and fascinated by her. Despite being intelligent and possessing all the above-described qualities, she is entangled with nineteenth century's ideologies of women. Isabel's humanity is ignored, and she is objectified by her husband Osmond, claiming that "had qualified herself to figure in his collection of choice objects" (p. 253) and Isabel believes that if it were anything, Osmond would have wanted her to have nothing except for her beautiful appearance (p. 359). Here it is shown that her whole existence and individuality 
is ignored and is known just for her mere appearances which count not much. Notwithstanding her intellect, she is shown to be a victim to scheming Madam Merle and Gilbert Osmond, she unwittingly accepts Gilbert's proposal of marriage "on a factitious theory, in order to do something finely appreciable with the money" (p. 358) despite the pact she had with herself of not marrying soon. Isabel is depicted to be a weak-willed woman with no significant decision of her own. She acts as a puppet to Madam Merle's plans. Gilbert has married her just for her with the help of Gilbert's old lover Serene Merle and she is expected in her marriage to play the role of Pansy's mother and be satisfied with title the marriage has offered her. The women of Victorian time period do not have any sort of authority to exercise, neither to decide for themselves nor to undecide certain ties. Isabel along with the female characters are depicted to marginalized and cornered.

The discourses of gender subjectivity and deeply entrenched ideological gender marginalization occupies a central space within the landscape of the whole novel. Almost, at every stage, almost all the female characters are expected to meet the standards held for women. Isabel, when comes to know about the ex-relationship of Osmond and Merle, she is forced to accept and come in terms with the discovery, although she is no longer loved by her husband. It shows once a decision is taken for a woman, she cannot undecide it at the cost of her life. She must suffer and remain in the quagmire knowingly. Lazar (2005) states that gender as a category of society interacts with many divergent categories of social hierarchy such as social class, position, geographical location, sexuality and ethnicity. Isabel is marginalized and taken for granted just because she is a woman, she is expected to happy in her unhappiness. Isabel knows that her husband disapproves of her because she has not effaced herself and she as a wife willingly has sacrificed her individuality and her opiniated self. Even with her husband's tyranny in the private sphere, she cannot dissolve the commitment because of the ideology of marriage. In the process of becoming a so-called lady, Henry James believes a woman must undergo many educating experiences at the cost of her happiness, freedom, endurance and tolerance. The lady is somebody who has acquired wisdom from her exposure to hard and trying times. Now the question arises why a woman must become a lady, why not a man be a gentleman. Almost all the men characters are bad or scheming but never a single insinuation is made about their cruelty throughout the whole text, it shows their malice is taken to a part of nature and they do not have to conform to rules while it is mandatory for women to follow rules of the society otherwise, they would be regarded as outcasts. These standards of ladies are mostly indoctrinated from a very young age that is why these ideologies are hard to eradicate (Lazar, 2005). Moreover, we note Pansy Osmond, young girl of fifteen years old, the only child of Gilbert Osmond, received her early education in a Swiss convent. She obeys her father in every way. She is educated in a way as to have no will of her own, the convent has taken out every enthusiasm the girl might have and all that remains of her is the empty shell of a body. Her father describes her as "a little convent flower" (p. 220), assuming that she is a nun who does not have any wish of her own. She is made so disciplined as not give vent to the feelings she has for Ned Rosier, whom she wishes to marry but dare not but he is a poor and underprivileged artist with no riches at all. When she shows her interest in the man she loves, she is sent back by her father to the convent 
for some so-called "finishing touches" (p. 442). In order to be socially acceptable, she is forced to conform to the ideology of a presentable woman, who obeys every wish of her parents, does not have any craving for anything, is an acquiescing human being. Her personality is snatched from her, she is repressed in everything for her father thinks that that is the ideal up bringing all females should have. She is described as "impregnated with the idea of submission" (p. 202). The patriarchal ideology is so set in her mind that she does not dare to question the status quo. Women are "blank pages" (p. 268) to be written by the men that somebody else has chosen for them. Waiting which is thought to be a feminine characteristic is alleged to Pansy, she decides to wait for Ned rather than going against her father's will.

Another woman character to note is countess Amy Gemini. She is the wife of Count Gemini, who has married her in order to take vengeance on her and make her miserable. She has married that "low-lived brute" (p. 449) who is a flirt and womanizer. She knows her husband dislikes her, but she chose to remain with him. It shows that women are nothing without the companionship of a man, in order to have a social footing a woman can survive only on the boat of marriage. Marriage is depicted to be a sacred commitment which must not be dissolved at the cost of unhappiness and misery. Amy has chosen the path because she knows she would not be acceptable in the society without the name of her so-called husband.

One of the most sinister characters in The Portrait of a Lady is that of Madam Merle. She is a shrewd and cunning woman and a reputed socialite in Europe. She carries a charm within her which is acquired only through experience and exposure. She is flawless and knows everything as it is stated by Mrs. Touchett. Madam Merle is apparently acceptable everywhere, but she is shown to be a vile creature within. Although she is the one who traps Isabel into marrying someone who does not love her, she is not solely responsible for her actions, as a mother and woman, she wishes that her daughter should have the life she desired for herself, that of riches and wealth, she is a victim to the ideology of an acceptable woman, she is unable to claim her child because of the society and its rules for women, though men could have whatever they want, be illegitimate children or marrying again despite being involved with someone else at the same time.

Isabel Archer's aunt Mrs. Touchett is responsible for bringing her to Europe from America. She comes off as a cold and practical woman. Mrs. Touchett does not follow the patriarchal rules of gender. She lives on her own terms away from her ill husband. But for her this choice of life, she is criticized and censured, often termed throughout the whole text as "crazy aunt Lydia" (p. 127). A good woman according to the patriarchal ideologies is someone who does not have a life of her own, who is mentally and physically dependent on a man, who takes care of her children and her husband, and if that husband is sick, it is her duty to stay beside husband in order to take care of him but Mrs. Touchett has exempted herself from these rubrics, that is why she is portrayed not in a very good light by the writer who of course is a man.

Furthermore, Isabel's best friend Henrietta Stackpole is a self-sufficient, ambitious and a bold American journalist. Although she is depicted to be an independent woman, with an income, the concept of subordination of women to men, is too prominent in the novel. Henrietta who lives independently and respectfully, at last marries old Mr. Bantling. Women, however, 
bold and ambitious are at last forced by the society to choose marriages whether desirable or undesirable.

As Arnfred (2002) quotes Simone de Beauvoir in his work that one is not born a woman but rather becomes one. This quote succinctly contextualizes the representations of female characters in the novel. Every female character is forced by the patriarchal society to conform to the ideologies set forth for them, just like they are forced to become a woman and be a subject, who as a receptacle receives all the negative things, the men exude, such as their anger, their torture and ill will. Moreover, if we analyse James' women characters as marginalized voices who suffer social exclusion, it would not be amiss. Given that marginalization underscores the procedures in which groups are partially or wholly exempted from taking part in the society where they live, often that exclusion is not limited only to participating in the society, but is carried out on many different levels, such as restricting women to certain domains. Women have faced subordination and marginalization from time immemorial, the marginalization of women in the novel The Portrait of a Lady is very much clear from the onset of the story. The protagonist Isabel was ready to take accountability for her fate and had high hopes for the future and was ready not to marry anyone, but she ended up in marrying Osmond, it is because she was compelled by the society and the expectations of Victorian time period. An unmarried woman is often regarded not in a good light, is often thought as an outcast in the society, therefore women choose marriage over their dreams of something better in order to avoid exclusion. In Victorian era, women and men are depicted to have separate interests, when gathered in a party, they spilt up during the party to play or discuss, men to go and discuss politics, sports, games and so on while women to discuss men. These sorts of portrayals give birth to women' marginalization to limited spheres and men to broadly exercise their will to the enjoyments of life.

James' The Portrait of a Lady can be viewed as a substantive account of Victorian discourses on marriage. Within the novel, marriage unlike the felicitous meeting of two minds and souls, but rather marriage is shown in the novel as a status which must be achieved by women, without it, they are shown as crippled and crawling beings notwithstanding ample sources of income. Many female characters are depicted to feel that marriage is essential, and a must-have thing at the cost of one's happiness and dreams. Taking the example of Pansy Osmond, she is brought up in such a way as to an obsequious and docile being in the hands of her father. She is the perfect example of patriarchal moldings, because she does not have a decision or a will of her own and any man would be happy to have such a submissive wife. Marriage is presented to have shackles, if worn once, it can never be got ridden off.

The novel encompasses the reining discourse on gendered subjectivity. In describing the conditions of expatriates in Europe, Madam Merle contrasts the situations of expatriates to that woman at large, maintaining that "a woman perhaps can get on, a woman it seems has no natural place anywhere; wherever she finds herself she has to remain on the surface and more or less to crawl" (p. 248) Women like expatriates have no place of their own, though expatriates have a country they call their own, but women on the other hand do not have a single permanent place to claim. Women face estrangement and alienation because of the so-called patriarchal ideologies, they are not 
even linked to a certain nation and or a private sphere of their own. Whatever position, location and status they are in, they must crawl in order to have a footing.

Ralph Touchett on the other hand claims that women are mere passive and submissive extensions of men who are powerful and active. He notes, "Most women did with themselves nothing at all, they waited, in attitudes more or less gracefully passive, for a man to come and furnish them with a destiny" (p.146). Women have no destiny or life of their own, they wait along the way for a man to come and a create a destiny for them. Women are regarded as receptacles for subjectivities designed and sustained by patriarchal discourses. Women standing and doing something for themselves is a concept alien to patriarchal men such as typified by Gilbert Osmond in the novel. Ralph also comments on his mother's taking the paternal role, regarding his mother not in a very good light, because the paternal roles have a dominance which maternal roles lack, that is why Ralph dislikes her for assuming a role not suited for females.

Moreover, a glaring instance which showcases gender subjectivity is the absence of focus on female rites. Some of the events which are of consequence, are deliberately dimmed and obliterated such as Isabel's childbirth, the birth of Isabel's first child receives only a passing comment by Madam Merle. The patriarchal and man-regulated presence in the text is unescapable in such way as to be hardly unnoticeable.

\section{Conclusion}

Henry James The Portrait of a Lady reflects the plight of women and their inferior place in society, the plight has emerged because of the gender ideologies that women's subordinate place and their marginalization as the "other" existing at the peripherals on the social strata, is taken to be normal. As analyzed under the prism of feminist critical discourse analyses, it emerges that power relations exploit discourse practices to create a chosen destiny for women and sustain it at the same time, suggesting that these identities of women are maintained and created so that patriarchal agenda remains intact. Gender subjectivity is upheld through a multi-pronged appeal to inherent Victorian discourses. An essentially flawed gender ideology governs the depiction of women characters within the novel. This gender illustration is marred given the web of subtle ideologies of patriarchal arch. The final portrait showcases a gender discourse that seeks to perpetuate a lot of women as suppressed, repressed and subjected to power structures of gender discourse. It is baffling that the protagonist Isabel, despite her aversion to her situation, cannot abjure the sanctity of marriage and goes back to her tormentor. She is made to abide by her commitment to her so-called marriage. Isabel remains under constrains and unable to exercise her free will to get rid of Osmond, despite having a fortune and no restrictions imposed on her. It stands to reason to argue that Isabel chose her lot as she was aware of the ideologies held for divorcees in Victorian time period. Pansy, who has been instilled in gender ideologies from childhood, does not have a will of her own and functions as a puppet in the hands of her father. Her personality is maintained by her father, directing and commanding her repressed self all the time. Mrs. Touchett, though she is depicted to be a rather independent woman, but she is not in the good books of anyone because she has swayed in her role of mother, she has chosen a life 
where she lives alone deviating from the social standards of a woman. The results of the study show that women, whether financially independent as in the case of Isabel or endowed with impendence of spirits like Touchett and Henrietta Stackpole, liberal as in the case of Madam Merle, wealthy as in the case of Countess Amy Gemini and innocent and educated just like Pansy Osmond, everywhere women are in shackles and bound to the male dominated, patriarchal society.

\section{Conflict of Interest Statement}

The authors declare no conflicts of interests.

\section{About the Authors}

Shah Mir is currently pursuing a PhD in English Literature and Culture from Atilim University, Ankara, Turkey. His core interest areas are Discourse Analysis, Critical Theory and Semiotics.

Saima Jahangir is a Lecturer in English at Labella University of Agriculture, Water and Marine Sciences, Pakistan.

\section{References}

Arnfred, S. (2002). Simone de Beauvoir in Africa:" Woman= The second sex?" Issues of African feminist thought. Jenda: A Journal of Culture and African Women Studies, 2(1).

Berg, B. (2007). Qualitative Research Method for Social Sciences. Routledge.

Brown, M. A. (1996). Modes of female social existence and adherence in Henry James's The Portrait of a Lady.

Butler, J. (1990). Gender trouble: Feminism and the subversion of identity. New York, NY: Routledge.

Dalton, E. (2015). Women and politics in contemporary Japan. Routledge.

Fairclough, N. (2003). Analysing discourse: Textual analysis for social research. London: Routledge

James, H. (1881). The Portrait of a Lady: 1881. Infomotions, Incorporated.

Khan, H. (2019). A Feminist Critical Discourse Analysis of Qaisra Shahraz's The Holy Woman in the Backdrop of Subalternity. International Journal of English Linguistics, 9(5), 249-256.

Lazar, M. M. (2005). Feminist critical discourse analysis: Gender, power, and ideology in discourse (Ed.). NY: Palgrave Macmillan

Lazar, Michelle. 2007. "Feminist Critical Discourse Analysis: Articulating a Feminist Discourse Praxis." Critical Discourse Studies 4 (2): 141-164. doi:10.1080/17405900701464816.

Lehtonen, S. (2007). Feminist critical discourse analysis and children's fantasy fiction-modelling a new approach. Past, present, future-From women's studies to post-gender research, 14-17.

Mendrofa, M. P. (2020). Feminist critical discourse analysis to the language use and display in whitening cosmetic product advertisements. SAGA: Journal of English Language Teaching and Applied Linguistics, 1(2), 119-126. 
Nartey, M. (2021). A feminist critical discourse analysis of Ghanaian feminist blogs. Feminist Media Studies, 21(4), 657-672.

Neculeac, A. M. (2020). Ambiguity, light and darkness in Henry James's The portrait of a lady.

Ohito, E. O., \& Nyachae, T. M. (2019). Poetically poking at language and power: Using Black feminist poetry to conduct rigorous feminist critical discourse analysis. Qualitative Inquiry, 25(9-10), 839-850.

Shapiro, B. (2017). Examining portrayals of female protagonists by female screenwriters using feminist critical discourse analysis. The Young Researcher, 1(1), 37-47.

Sohier, J. (2015). Henry James's The Portrait of a Lady: The Figure of the Lady Between Surplus Value and Surplus Enjoyment. Miranda. Revue pluridisciplinaire $d u$ monde anglophone/Multidisciplinary peer-reviewed journal on the English-speaking world, (11).

Sunderland, Jane and Lia Litosseliti 2002. Gender Identity and Discourse Analysis. Theoretical and Empirical Considerations, in L. Litosseliti (ed.) Gender Identity and Discourse Analysis, Philadelphia: John Benjamins, 1-39.

Van Dijk, J. A. (2005). The deepening divide: Inequality in the information society. Sage Publications.

Van Dijk, T. A. (1993). Principles of critical discourse analysis. Discourse and Society, 4, 249 283. 
Creative Commons licensing terms

Author(s) will retain the copyright of their published articles agreeing that a Creative Commons Attribution 4.0 International License (CC BY 4.0) terms will be applied to their work. Under the terms of this license, no permission is required from the author(s) or publisher for members of the community to copy, distribute, transmit or adapt the article content, providing a proper, prominent and unambiguous attribution to the authors in a manner that makes clear that the materials are being reused under permission of a Creative Commons License. Views, opinions and conclusions expressed in this research article are views, opinions and conclusions of the author(s). and European Journal of Literature, Language and Linguistics Studies shall not be responsible or answerable for any loss, damage or liability caused in relation to/arising out of conflicts of interest, copyright violations and inappropriate or inaccurate use of any kind content related or integrated into the research work. All the published works are meeting the Open Access Publishing requirements and can be freely accessed, shared, modified, distributed and used in educational, commercial and non-commercial purposes under a Creative Commons Attribution 4.0 International License (CC BY 4.0). 